\title{
PENGARUH PENGGUNAAN MEDIA PEMBELAJARAN BERBASIS FILM TERHADAP HASIL BELAJAR IPS SISWA SMP MATERI POTENSI DAN PEMANFAATAN SUMBER DAYA ALAM
}

\author{
Siti Nahdiroh ${ }^{1}$, Risma Dwi Arisona ${ }^{2}$ \\ ${ }^{1}$ Institut Agama Islam Negeri Ponorogo \\ Sitinahdiroh@gmail.com \\ ${ }^{2}$ Institut Agama Islam Negeri Ponorogo \\ arisona@iainponorogo.ac.id
}

\begin{abstract}
Media is a tool that helps in the learning process. Assistive devices that are able to represent something that an educator or teacher cannot convey through words or sentences. Researchers used a quantitative approach with a quasi-experimental method, the design used was nonequeivalent control group design. This means that research that examines the relationship between the variable use of film-based media (variable $X$ ) and ips learning outcomes in material potential and utilization of natural resources (variable $Y)$. The population of this research was all class VII SMPN 5 Ponorogo, the sample used in this study was only class VII A as the control class and VII B as the experimental class. Data collection using tests and documentation, test instruments in the form of questions totaling 30 questions. The types of tests used are pre-test and post-test. To test the data hypothesis, the calculation results are used in the t-test column. Based on the t-test table, it is known that the Sig. (2-tailed) is 0.020. By using a 95\% confidence level, the Sig. 0.020 is less than $0.05(0.020<0.05)$. So it can be concluded that there is a significant effect of using film-based learning media on social studies learning outcomes on the potential and utilization of natural resources.

Keywords: Learning Media; film; social studies learning outcomes
\end{abstract}

\section{ABSTRAK}

Media merupakan alat bantu yang membantu dalam proses pembelajaran. Alat bantu yang mampu mewakili sesuatu yang tidak dapat disampaikan pendidik atau guru melalui kata-kata atau kalimat. Peneliti menggunakan pendekatan kauntitatif dengan metode quasi experiment, desain yang digunakan nonequeivalent control group design.. Artinya penelitian yang menguji hubungan antara variabel penggunaan media berbasis film (variabel X) dan hasil belajar ips dalam materi potensi dan pemanfaatan sumber daya alam (variabel Y). Populasi penelitian ini adalah seluruh kelas VII SMPN 5 Ponorogo, sampel yang digunakan pada penelitian ini hanya kelas VII A sebagai kelas kontrol dan VII B sebagai kelas eksperimen. Pengumpulan data dengan menggunakan tes dan dokumentasi, Instrumen tes berupa soal yang berjumlah 30 soal. Jenis tes yang digunakan adalah tes pre-tes dan post-test. Untuk uji hipotesis data, digunakan hasil perhitungan pada kolom $t$-test. Berdasarkan tabel t-test, diketahui nilai Sig. (2-tailed) yaitu 0,020. Dengan menggunakan taraf kepercayaan 95\%, maka nilai Sig. 0,020 kurang dari 0,05 $(0,020<0,05)$. Maka dapat disimpulkan bahwa ada pengaruh yang signifikan penggunaan media pembelajaran berbasis filem terhadap hasil belajar IPS materi potensi dan pemanfaatan sumber daya alam.

Kata kunci: Media Pembelajaran; film; hasil belajar IPS

Copyright (c) 2020 Siti Nahdiroh, Risma Dwi Arisona 
Penggunaan Media Pembelajaran Berbasis Film Terhadap Hasil Belajar IPS Siswa SMP Materi

Potensi dan Pemanfaatan Sumber Daya Alam

\section{PENDAHULUAN}

Pembelajaran merupakan proses aktif peserta didik yang mengembangkan potensi yang dimiliki dalam diri peserta didik. Peserta didik dilibatkan kedalam pembelajaran yang didampingi oleh guru sehingga pelajar mengalir dalam pembelajaran yang melibatkan pikiran, emosi, sehingga terjalin dalam kegiatan yang menyenagkan dan mendorong prakarsa (upaya atau tindakan) siswa dalam kegiatan pembelajaran. Terdapat beberapa hal yang melandasi aktivitas dan prosesnya. Robet M. Gagne dan Leslie J. Briggs yang dikutip oleh Dadang Supardan, dalam bukunya yang berjudul Pembelajaran Ilmu Pengetahuan Sosial, memaparkan beberapa pendapat yang melandasi proses pembelajaran. Pertama, pembelajaran yang bertujuan memberikan bantuan agar belajar siswa menjadi lebih efektif dan efisien. Kedua, pembelajaran bersifat terprogram, dalam hal ini yang dimaksud adalah pembelajaran dirancang untuk tujuan jangka pendek, menengah ataupun jangka panjang. Ketiga, pembelajaran dirancang dengan pendekatan sistem. Keempat, pembelajaran yang dirancang harus sesuai berdasarkan pendekatan yang sistematis. Kelima pembelajaran dirancang berdasarkan pengetahuan tentang teori belajar. ${ }^{1}$

Pembelajaran sebenarnya tidak semudah apa yang kita pikirkan atau kita bayangkan sebab dalam kenyataannya, pendidik (guru) sering kali dihadapkandengan kendala yang datang dari dalam maupun dari luar lingkungan pembelajaran, baik fisik maupun non fisik. Kualitas pembelajaran yang masih kurang di dalam kelas, ditandai dengan rendahnya aktivitas peserta didik di dalam kelas, misalnya ketika proses pembelajaran berlangsung peserta didik tidak memperhatikan guru di kelas, peserta didik ramai ketika proses pembelajaran, peserta didik belum aktif dalam proses pembelajaran di kelas, serta belum aktifnya peserta didik dalam kegiatan kelompok. Melihat berbagai masalah yang terjadi didalam kelas maka diperlukan suatu persiapan dalam pembelajaran untuk meningkatkan kualitas pembelajaran di kelas. Guru-guru dituntut kreatif menemukan dan menciptakan macam-macam media. Media yang efektif bermuatan bermacam pesan. Salah satu langkah yang dapat digunakan adalah dengan menggunakan media pembelajaran.

Pada mulanya media yang dianggap sebagai alat bantu dalam peroses mengajar pada waktu itu hanyalah alat bantu, yang berupa model, objek dan alatalat lain yang dapat memberikan pengalaman konkret seta mempertinggi daya serap para peserta didik. Kemudian pada tahap selanjutnya mulailah muncul pengaruh teknologi audio yang melengkapi pengguaan alat bantu visual tersebut. Pada akhirnya, kombinasi alat bantu audio visual untuk membantu pembelajaran ini disebut dengan audio visual aids (AVA). Media pembelajaran memiliki sejumlah manfaat penting diantaranya (1) Mengatasi perbedaan pengalaman (2) Mengkonkretkan konsep-konsep yang abstrak (3) Mengatasi keterbatasan (4) Interaksi langsung (5) Mengasilkan keragaman pengamatan (6) Menanamkan 2015), 1 .

${ }^{1}$ Dadang Supardan, Pembelajaran Ilmu Pengetahuan Sosial, (Jakarta: PT Bumi Aksara, 
kosep dasar yang benar konkret, dan realistis (7) Merangsang dan membangkitkan motivasi untuk belajar (8) Membangkitkan keinginan dan minat guru (9) Memberikan pengalaman integral ${ }^{2}$

Media pembelajaran menepati kedudukan yang penting sebagai salah satu komponen sistem pembelajaran. Tanpa media, komunikasi tidak akan terjadi dan proses pembelajaran sebagai proses komunikasi juga tidak bisa berlangsung secara optimal. Media pembelajaran adalah komponen yang utuh dari sistem pembelajaran. Dalam proses pembelajaran, media memiliki peran sebagai pembawa informasi dari sumber (guru) menuju penerima (siswa). Dalam kegiatan interaksi antara siswa dengan lingkungan, kegunaan media dapat diketahui atas adanya kelebihan media dan hambatan yang mungkin timbul dalam proses pembelajaran.

Penerapan media film dalam penyamapaian pembelajaran tidak dapat berjalan atau berdiri sendiri. Hal ini karena film hanyalah sebagai media pelaksana bukan metode pembelajaran. Media film digunakan agar dapat menarik dan mampu memberikan penjelasan yang mencakup aspek sikap dan psikomotor. Berikut beberapa keunggulan film sebagai media pembelajaran (1) Mampu menangkap, menyimpan, menyampaikan kembali suatu obyek atau kejadian yang sesungguhnya (2) Mampu menyajikan kejadian dalam waktu singkat, peristiwa yang sebenarnya bertahun-tahun dapat disajikan dalam waktu tertentu (3) Mampu menembus keterbatasan ruang dan waktu atau membawa dunia kedalam kelas dan dapat lebih menarik perhatian dan meningkat motivasi belajar siswa. ${ }^{3}$

Berdasarkan hasil wawancara awal yang dilakukan pada saat magang 2 di SMPN 5 Ponorogo, menunjukkan bahwa, pembelajaran IPS masih menghadapi berbagai macam permasalahan. Permasalahan itu diantaranya dalam proses pembelajaran guru lebih banyak menggunaan buku-buku paket yang didominasi oleh materi pembelajaran dalam bentuk taks. Mereka juga juga mengemukakan bahwa peserta didik seringkali kurang memperhatikan dalam proses pembelajaran yang diduga dikarenakan materi IPS dianggap membosankan dan tidak menyenangkan. Kedudukan media pendukung pembelajaran dengan menggunakan berbagai media berbasis teknologi seperti film sebenarnya juga sudah tersedia disetiap kelas. Namun penggunaannya hanya sebatas penayangan materi melalui Power Point. Penggunaan film dalam kegiatan pembelajaran IPS jarang dilakukan dengan alasan ketiadaan film yang bisa digunkan untuk kegiatan pembelajaran. Berbagai masalah tersebut turut berpengaruh terhadap tingkat ketuntasan hasil belajar siswa yang sangat beragam dan tidak selalu menggembirakan, ada siswa yang hasil belajar IPSnya tinggi, ada yang sedang, adapula beberapa dari mereka yang hasil belajarnya rendah.

${ }^{2}$ Donni Juni Priansa, Pengembangan Strategi dan Model Pembelajaran, (Bandung: Pustaka Setia, 2017) 131-132.

${ }^{3}$ Agus Eka Saputra \& slamet Priyanto, Penerapan Metode Demontrasi dan Media Film untuk Meningkatkan Keaktifan dalm Pembelajaran dan Prestasi Belajar Sitem Rem, Jurnal Taman Vokasi, Vol. No 4, 2 Desember 2016, 155-156. 
Penelitian ini Film dokumenter yang digunakan adalah film yang berjudul Sexy Killers, film yang ditrisbusikan oleh Watchodoc ini meengupas tuntas kisah fakta terkait pertambangan di Indonesia. Watchdoc seolah ingin menyadarkan pentonton dengan megangkut isu seksi yang relevan dengan iklim Indonesia. Film ini menyuguhkan fakta kelam dibalik terangnya lampu-lampu kota yang dapat memberikan persepektif lain terhadap usaha pemeritah memenuhi kebutuhan listrik di indonesia. Film ini dibuka dengan adegan uyang cukup provokatif yakni pasangan suami istri yang sedang berbulan madu dengan perhitungan listrik yang dipakai, dari alur itu kemudia langsung beralih dari bingarnya listrik kota ke kisah gelap warna batu bara. Batu bara merupakan sumber daya penghasil energi listrik.

Penonton diajak kepinggir kota samarinda yang memeperlihatkan tempat tinggal para petani yang berada didekat pertambang batu bara. Dalam film tersebut petani mengaku selama bertahun-tahun mengalami kerisis air bersih, sebab pertambang batu bara mengancurkan jalur air bersih, baik untuk kebutuhan sehari-hari maupun bertani. Sulitntya air bersih juga menyebabkan banyaknya penyebaran penyakit. Selain itu ada kematian anak- anak yang diakibatkan oleh aktivitas pertambang yang cukup dekat dengan kawasan sekolah dan peroses revitalisasi galian tambang yang tidak kunjung terlaksana.

Selain lokasi tambang batu bara, tempat konverasi batu bara menjadi aliran listrik juga turut bermasalah. Dalam film ini mengisahkan pembangunan PLTU Batang yang digadang- gadang akan menjadi PLTU terbesar Se-Asia Tenggara. Lokasinya yang berada dipinggir pantai tentunya kesibukan PLTU ini akan berdampak pada para nelayan, trasportasi kapal-kapal tongkang yang membawa batu bara akan mengakibatkan pencamuran laut dan terganggunya habitat ikan terumbu karang. Disini penonton akan menyaksikan sendiri keluhan dan pendapat dari warga yang terkena dampak langsung. Karena merusak ekosistem laut yang berdampak pada pengahsilan nelayan banyak dari warga yang sudah berupaya untuk melakukan penolakan pembangunan PLTU.Bulan Mei 2014, dua warga yakni (carman dan cahyadi) menolak menjual tanahnya untuk pembangunan PLTU, namun penolakan pembangunan PLTU ini akhirnya berjung kriminalisasi dan dijatuhi hukuman kurungan tujuh bulan.

Tidak hanya merusak mata pencaharian dan ekosistem alam, aktivitas PLTU tentu memberikan imbas pada kesehatan yang mengancam warga disekitarnya khususnya di pulau Sulawesi Tengah gambaran gangguan kesehatan hasil dampak PLTU dampaknya sangat serius. Khususnya banyaknya warga yang divonis mengidap penyakit alergi debu. Tidak hanya itu, banyak contoh lain yang ditampilkan di film ini, tampaknya masalah kesehatan paru-paru sangat serius dialamioleh warga palu, namun banyak yang belum sadar mengenai penyakit serius. ${ }^{4}$

${ }^{4} \mathrm{Http}: / /$ palu.tribunnews.com/2019/04/15/sinopsis-sexy-killers-film-dokumenter-kisahkanfakta-di-balik-terangnya-listrik-segelap-batu-bara. 
Tujuan dari penelitian ini adalah untuk mengetahui tingkat singnifikansi pengaruh penggunaan media pembelajaran berbasis film terhadap hasil belajar IPS Siswa SMP dalam materi potensi dan sumber daya alam. Manfaat yang penulis harapkan dari penulisan penelitian ini adalah secara teoritis penelitian ini diharapkan dapat menguji teori tentang ada ataupun tidaknya pengaruh penggunaan media pembelajaran berbasis film terhadap hasil belajar IPS dalam materi materi potensi dan sumber daya alam. Secara Praktis bagi lembaga sebagai masukan tentang pentingnya penggunaan media pembelajaran berbasis film terhadap hasil belajar ips dalam materi materi potensi dan sumber daya alam siswa kelas VII SMPN 5 Ponorogo. Bagi sekolah/guru untuk memberi pengetahuan akan pentingnya penggunaan media pembelajaran berbasis film terhadap hasil belajar ips dalam materi materi potensi dan sumber daya alam siswa kelas VII SMPN 5 Ponorogo.

\section{METODE PENELITIAN}

Rancangan penelitian ini, peneliti menggunakan pendekatan kauntitatif, yaitu pendekatan penelitian yang menggunakan data berupa angka yang digunakan untuk meneliti populasi atau sampel. Dengan metode quasi experiment, desain yang digunakan nonequeivalent control group design. Artinya penelitian yang menguji hubungan antara variabel penggunaan media berbasis film (variabel $\mathrm{X}$ ) dan hasil belajar ips dalam materi potensi dan pemanfaatan sumber daya alam (variabel Y). Tenik pengumpulan data yang digunakan dalam penelitian ini adalah tes dan dokumentasi. Metode analisis data menggunakan t-test yang dibantu dengan program SPSS Versi 25.

\section{HASIL DAN PEMBAHASAN}

Data hasil belajar IPS diperoleh melalui tes esai yang berjumlah 30 soal yang terdiri dari 25 soal piliihan ganda dan 5 soal isai sebelum diujicobakan, divalidasikan terlebih dahulu kepada ahli desain pembelajaran. Instrumen yang sudah divalidasi diujicobakan pada kelas VII C SMPN 5 Ponorogo, setah soal di uji cobakan baru kemudain soal akan di berikan ke kelas eksperimen dan kontrol yakni kelas VII B dan V II A. Penyususnan soal tes harus berimbang dilihat dari tingkat kesukaran dengan prosentasetingkat kesulitan tinggi, sedang maupun mudah.Penelitian ini mengunakan pretest dan posttest.

Pre-Test atau Kemampuan Awal Siswa Pre-test dalam penelitian ini dilaksanakan pada kelas VII B sebagai kelas eksperimen dan kelas VII A sebagai kelas Kontrol. Pre-testmerupakan nilai yang diperoleh dari hasil tes kelas eksperimen dan kontrol sebelum menerima pembelajaran. Pre-test bertujuan untuk mengetahui besar kemampuan awal siswa kelas eksperimen dan kontrol. Hasil nilai rata- rata kemampuan awal (pre-test) kelas VII A sebagai kelas kontrol sebesar 66, dan kelas VII B sebagai kelas eksperimen sebesar 65,3. Nilai tersebut menunjukkan bahwa nilai rata-rata kelas VII B lebih rendah dari kelas VII A. selisish nilai kelas VII A dan VII B sebesar 0,7. 
Post-Test atau Kemampuan Akhir Siswa Post-test dalam penelitian ini dilaksanakan pada kelas VII B sebagai kelas eksperimen dan kelas VII A sebagai kelas Kontrol. Post-testmerupakan nilai yang diperoleh dari hasil tes kelas eksperimen dan kontrol setelah menerima pembelajaran. Post-test bertujuan untuk mengetahui besar kemampuan akhir siswa kelas eksperimen dan kontrol. Hasil rata-rata nilai akhir (Post-test) kelas VII A sebagai kelas kontrol sebesar 70,9 dan kelas VII B sebagai kelas eksperimen sebesar 79,6. Nilai tersebut menunjukkan bahwa nilai rata-rata kelas VII B lebih tinggi dari pada kelas VII A dengan selisih 8,7 .

Pengujian hipotesis penelitian ini menggunakan data gain score tersebut diperoleh dengan cara mengurangi nilai post-test dengan nilai pre-test. Berdasarkan perhitungan rata-rata gain score kelas eksperimen yakni kelas VII B sebesar 11, 6 dan kelas kontrol sebesar 4,9. Besar kecilnya nilai rata-rata gain score yang diperoleh kelas eksperimen maupun kelas kontrol dipengaruhi oleh besar kecilnya nilai pretest dan posttest yang diperoleh.

\section{Gambar 4.1 grafik gain score}

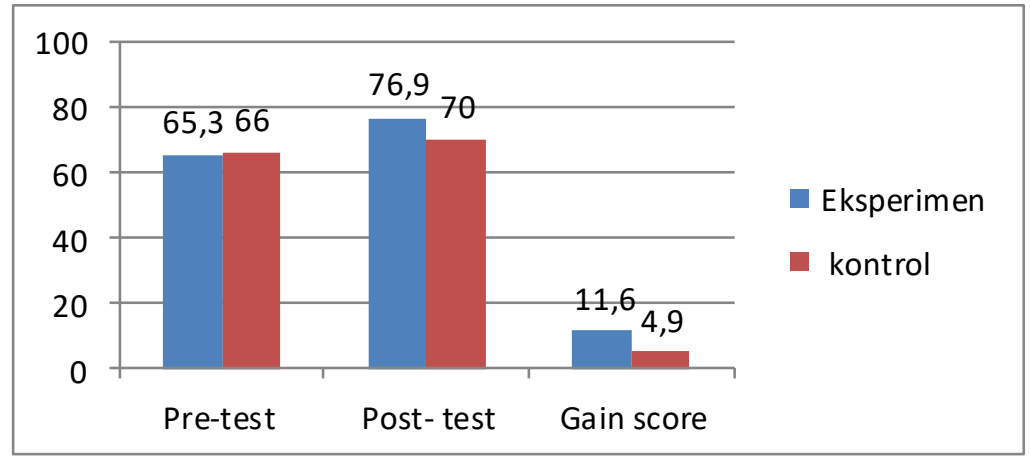

Hasil penelitian berupa data gain score dianalisis dengan menggunakan independen sampel t test (uji t). hasil analisis digunakan untuk menguji hipotesis yang telah dirumuskan. Namun, sebelum dilakukan pengujian hipotesis ajan dilakukan uji normalitas data terlebih dahulu. Uji normalitas tersebut merupakan salah satu uji prasyrat sebelum dilakukan analisis data lebih lanjut. Hail uji normalitas data yang telah dihitung dengan program SPSS Versi25 uji normalitas data eksperimen dan kelas kontrol dengan menggunkanan analisis kolmogrorovsmirnov. Kriteria data yang tergolong distribusi normal adalah jika nilai sig > 0,05 . Keduanya memiliki nilai 0,200. Setelah diketahui normalitas dari kedua kelas tersebut maka dapat dilakukan uji hipotesis dengan uji statistik inferensial menggunkan uji- t yaitu Independent Sampel Test. Hasil uji -t yang telah dihitung dengan program SPSS Versi 25 dapat dilihat pada tabel dibahaw ini. 


\begin{tabular}{|c|c|c|c|c|c|c|c|c|c|c|}
\hline & & \multicolumn{2}{|c|}{$\begin{array}{l}\text { Levene's Test } \\
\text { for Equality } \\
\text { of Variances }\end{array}$} & \multicolumn{7}{|c|}{ t-test for Equality of Means } \\
\hline & & $\mathrm{F}$ & Sig. & $\mathrm{T}$ & df & $\begin{array}{l}\text { Sig. } \\
(2- \\
\text { tailed })\end{array}$ & $\begin{array}{l}\text { Mean } \\
\text { Differ } \\
\text { ence }\end{array}$ & $\begin{array}{l}\text { Std. Error } \\
\text { Differenc } \\
\text { e }\end{array}$ & $\begin{array}{l}95 \% \quad \text { Co } \\
\text { Interval } \\
\text { Difference } \\
\text { Lower }\end{array}$ & $\begin{array}{l}\text { idence } \\
\text { the } \\
\text { Upp } \\
\text { er }\end{array}$ \\
\hline \multirow[t]{2}{*}{ HASIL } & Equal variances assumed & 5,858 & ,018 & $\begin{array}{l}2,3 \\
86\end{array}$ & 62 &, 020 & $\begin{array}{l}6,718 \\
75\end{array}$ & 2,81541 & 1,09084 & 12,3 \\
\hline & $\begin{array}{l}\text { Equal variances not } \\
\text { assumed }\end{array}$ & & & $\begin{array}{l}2,3 \\
86\end{array}$ & $\begin{array}{l}55 \\
02 \\
0\end{array}$ &, 020 & $\begin{array}{l}6,718 \\
75\end{array}$ & 2,81541 & 1,07660 & $\begin{array}{l}12,3 \\
6090\end{array}$ \\
\hline
\end{tabular}

Berdasarkan tabel diatas menunjukkan bahwa analisis data dengan menggunakan Independent sampels Test terdapat kolom hasil perhitungan Levene's Test dan t-test. Kolom Levene's Test digunakan untuk mengetahui homogenitas data. Kriteria data yang homogen adalah jika nilai Sig. > 0,05. Berdasarkan tabel di atas, nilai Sig. pada kolom Levene's Test adalah 0,018> 0,05, sehingga dapat disimpulkan bahwa data tersebut adalah normal . Untuk uji hipotesis data, digunakan hasil perhitungan pada kolom $t$-test. Berdasarkan tabel $t$ test, diketahui nilai Sig. (2-tailed) yaitu 0,020. Dengan menggunakan taraf kepercayaan 95\%, maka nilai Sig. 0,020 kurang dari 0,05 $(0,020<0,05)$. Maka dapat disimpulkan bahwa ada pengaruh yang signifikan penggunaan media pembelajaran berbasis filem terhadap hasil belajar IPS materi potensi dan pemanfaatan sumber daya alam.

Beberapa hasil penelitian sebelumnya juga menunjukkan adanya pengaruh media pembelajaran berbasis film terhadap hasil belajar siswa. Diketahui dari beberapa hasil penelitian terdahulu dengan meggunakan media pembelajaran berbasis film yang pernah dilakukan oleh hayyun Lathifaty (2016); Zulkham Fatturrakhman (2012); Agus Eka Saputra \& Slamet Priyatno (2016); Muharria, Syafruddin Yusuf, Sri Kartika (2016) menunjukkan bahwa pembelajaran dengan menggunakan media pembelajaran berbasis film secara langsung berpengaruh signifikan terhadap hasil belajar siswa, khususnya pada ranah kognitif yang dilakukan pada subjek penelitian yang berbeda.

Media merupakan alat bantu yang membantu dalam proses pembelajaran. Alat bantu yang mampu mewakili sesuatu yang tidak dapat disampaikan pendidik atau guru melalui kata-kata atau kalimat. Kefektifan daya serap siswa terhadap pelajaran yang sulit dan rumit dapat terbantu dengan bantuan media. Media pembelajaran diakui dapat melahirkan respon baik dari siswa. Tinggi rendahnya minat siswa terhadap materi pembelajaran banyak dipengaruhi oleh media pembelajaran yang digunakan oleh seorang guru, media pembelajaran berbasis film atau audio visual adalah media pembelajaran modern dengan tujuan penggunaan media ini adalah untuk memudahkan siswa dalam memahami materi 
yang disampaikan oleh seorang guru, media pembelajaran, sebagaimana dikatakan Gagne adalah, berbagai jenis komponen dalam lingkungan peserta didik yang dapat memotivasi peserta didik untuk belajar. Media pembelajaran dapat dipahami juga sebagai segala sesuatu yang dapat digunakan untuk menyalurkan pesan dari guru kepada peserta didik ataupun sebaliknya sehingga dapat merangsang daya pikir, perasaan, ketertarikan peserta didik agar proses pembelajaran dapat berlangsung secara efektif. ${ }^{5}$

Penggunakan media pembelajaran dengan cara memanfaatkan media yang telah ada, Nana Sudjana dan Ahmat Rivai, mereka berpendapat bahwa dalam memilih media untuk kepentingan pengajaran sebaiknya memperhatikan tolak ukur sebagai berikut: (1) Ketepatannya pada tujuan pengajaran, artinya media pembelajaran dipilih atas dasar tujuan-tujuan intruksional yang telah ditetapkan. Tujuan-tujuan intruksional yang berisikan unsur-unsur pemahaman, aplikasi, analisis, sintesis, lebih mungkin digunakannya media pengajaran. (2) Dukungan terhadap isi bahan pelajaran: artinya bahan pelajaran yang sifatnya fakta, prinsip, konsep dan generalisasi sangat membutuhkan dukungan dari media pembelajaran agar lebih mudah dipahami peserta didik. (3) Kemudahan memperoleh media: artinya media yang diperlukan mudah diperoleh, setidak tidaknya mudah dikerjakan oleh guru pada saat mengajar. (4) Keterampilan guru dalam menggunakannya: nilai dan manfaat yang diharapkan bukan pada medianya, tetapi pengaruh dari penggunaannya oleh guru pada saat berlangsungya interaksi belajar peserta didik dengan lingkungannya. (5) Tersedia waktu untuk menggunakannya, sehingga media tersebut dapat bermanfaat bagi peserta didik selama pembelajaran berlangsung. (6) Sesuai dengan taraf piker siswa, sehingga makna yang terkandung didalamnya dapat dipahami oleh siswa. ${ }^{6}$

Tiga kelebihan kemampuan media ialah sebagai berikut, pertama kemampuan fiksatif, artinya media mampu menagkap, menyimpan dan menampilkan kembali suatu obyek atau kejadian. Dengan kemampuan ini, obyek atau kejadian dapat digambar, dipotret, direkam, difilmkan, kemudian dapat disimpulkan dan pada saat diperlukan dapat ditunjukkan dan diamati kembali seperti kejadian aslinya. Kedua kemapuan manupilatif, artinya media mampu menampilkan kembali obyek atau kejadian dengan berbagai macam perubahan (manipulasi) sesuai keperluan. Ketiga, kemampuan distributif, artinya media dapat mejangkau audien yang jumlahnya besar dalam satu kali penyajian secara serempak $^{7}$. Namun Kelemahan penggunaan media pembelajarn berbasis film diantaranya. Pertama ialah mahal, kedua jika film uyang digunakan kurang tepat akan berdampak kurang baik, Ketiga kurang efektif untuk memberikan pengajaran yang sesungguhnya. ${ }^{8}$

\footnotetext{
${ }^{5}$ Donni Juni Priansa, Pengembangan Strategi \& Model Pembelajaran, 130.

${ }^{6}$ Syaiful Bahri Djamarah dan Aswan Zain, Strategi Belajar Mengajar, (Jakarta: Rineka Cipta, 2010), 132-133.

${ }^{7}$ Buku Ajar Media Pembelajaran,( PDF, Zainuddin Tanjung,).

${ }^{8}$ Suparijanto, Pendidikan Orang Dewasa, (Jakarta: PT Bumi Aksara,2009), 176-177.
} 
Dari data hasil penelitian yang telah dilakukan menunjukkan bahwa penggunaan media pembelajaran berbasis film dokumenter dalam pembelajaran IPS sangat membatu karena dapat menyajikan sebuah peristiwa yang pernah terjadi dan sama dengan aslinya tanpa ada suatu rekayasa dari pihak tertentu. Peserta didik dapat membandingkan berbagai sumber yang ada sehingga pemahaman peserta didik sendiri dapat berkembang sesuai dengan keaktifan peserta didik.

Media film dokumenter mampu mendatangkan suasana pembelajaran yang lebih menyenangkan dan santai. Hal ini membuat peserta didik dengan mudah mengembangkan pemahamannya terhadap materi dengan cara mencari hal- hal yang berkaitan dengan film tersebut. Dari situlah film dokumenter membawa pengaruh yang segnifikan terhadap metode belajar pesrta didik, sehingga berkolaborasi dengan hasil belajar siswa yang lebih baik.

\section{PENUTUP}

Berdasarkan hasil analisis data, maka dapat disimpulkan bahwa penggunaan media pembelajaran berbasis filem terhadap hasil belajar IPS materi potensi dan pemanfaatan sumber daya alam mempunyai pengaruh yang signifikan. Media film dokumenter mampu mendatangkan suasana pembelajaran yang lebih menyenangkan dan santai. Hal ini membuat peserta didik dengan mudah mengembangkan pemahamannya terhadap materi dengan cara mencari hal-hal yang berkaitan dengan film tersebut. Dari situlah film dokumenter membawa pengaruh yang segnifikan terhadap metode belajar pesrta didik, sehingga berkolaborasi dengan hasil belajar siswa yang lebih baik. Hal ini dikarenakan media film menayangkan fenomena atau masalah yang nyata sehingga siswa mampu memahaminya secara mudah,mereka tidak salah pemahaman dan penayangan media film juga mampu menyatukan pemahaman antar siswa yang mana pada dasarnya setiap siswa memiliki pemikiran dan pemahaman yang tidak sama antara satu dengan yang lain. Sehingga scara ini sangat membatu untuk menigkatkan hasil beljar siswa.

\section{DAFTAR PUSTAKA}

Priansa, Donni Juni, Pengembangan Strategi dan Model Pembelajaran, Bandung: Pustaka Setia, 2017

Priyanto, Slamet \& Agus Eka Saputra, Penerapan Metode Demontrasi dan Media Film untuk Meningkatkan Keaktifan dalm Pembelajaran dan Prestasi Belajar Sitem Rem, Jurnal Taman Vokasi, Vol. No 4, 2 Desember 2016

Supardan, Dadang, Pembelajaran Ilmu Pengetahuan Sosial, (Jakarta: PT Bumi Aksara, 2015)

Suparijanto, Pendidikan Orang Dewasa, Jakarta: PT Bumi Aksara, 2009.

Tanjung, Zainuddin, Buku Ajar Media Pembelajaran, PDF 
Penggunaan Media Pembelajaran Berbasis Film Terhadap Hasil Belajar IPS Siswa SMP Materi Potensi dan Pemanfaatan Sumber Daya Alam

Zain, Aswan dan Syaiful Bahri Djamarah, Strategi Belajar Mengajar, Jakarta: Rineka Cipta, 2010. 